\title{
NOVOVEKÝ SÍDLISKOVÝ SEGMENT Z MUŽLE-ČENKOVA
}

\author{
MILAN HANULIAK
}

\begin{abstract}
Abstrakt: V polohe Orechový sad z katastra obce Mužla-Čenkov (okres Nové Zámky) sa v roku 1989 preskúmalo 9 sídliskových objektov. Patria $k$ nim dve zemnice s jazykovitým vstupom, štyri obilné zásobnice a tri zásobné jamy vzdialené od seba 3-8m na brehu rieky Dunaj. Ich reprezentanti tvoria súčast' sídliskového segmentu z prvej polovice 17. storočia. K ich chronologickému zaradeniu prispeli nepočetné zlomky keramických nádob, podkovičky z obuvi a zlomky delových gúl'. Po analýze nálezového fondu sa objasňuje význam príslušného segmentu v danom priestore, dôvod jeho vzniku i násilného zániku a výskyt militárii vagrárnom prostredí.
\end{abstract}

Kl'účové slová: Slovensko - včasný novovek - sídliskové objekty - materiálna kultúra.

\section{A Modern-Age Settlement Segment from Mužla-Čenkov}

Abstract: Nine settlement features were investigated at the Orechový sad location in the cadastral zone of Mužla-Čenkov (Nové Zámky district) in 1989. These included sunken features with a tongue-shaped entrance, four grain storage pits and three storage pits situated 3-8m from one another on the bank of the Danube. The features make up a part of a settlement segment from the first half of the 17th century. Their chronological classification was contributed to by sparse fragments of ceramic vessels, shoe heel tips and fragments of cannonballs. The analysis of the collection elucidated the importance of the segment for the location, the reasons behind its origin and violent decline, as well as the occurrence of militaria in the farming environment.

Key words: Slovakia - early modern age-settlement features - material culture.

Osada Čenkov je v súčasnosti vzdialená $7 \mathrm{~km}$ od strediskovej obce Mužla (okres Nové Zámky). Odbornej verejnosti je známa vd’aka opevnenému sídlisku z 9.-10. storočia, umiestnenému na l'avom brehu rieky Dunaj (Hanuliak-Kuzma 2015). V príspevku spracúvaný nálezový fond sa získal z deviatich objektov preskúmaných v roku 1989 vo východnom úseku lokality ležiacej v polohe Orechový sad (Hanuliak-Kuzma 1991, 36).

\section{Sídliskové objekty}

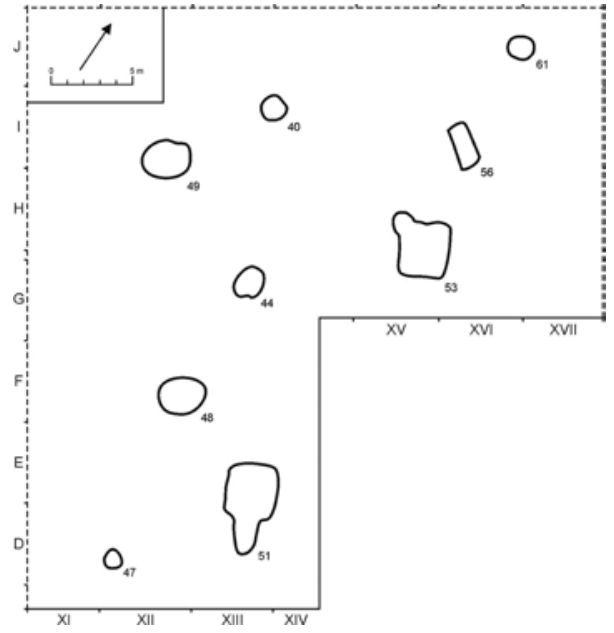

Obr. 1. Mužla-Čenkov. Plán sídliskového segmentu. Kresba M. Hanuliak.

Abb. 1. Mužla-Čenkov. Planskizze des Siedlungssegments. Zeichnung M. Hanuliak.
Podl'a spôsobu využitia patria zástupcovia $\mathrm{z}$ predmetnej kategórie $\mathrm{k}$ trom základným typom. Kolekciu tvoria dve zemnice, štyri obilné zásobnice a tri zásobné jamy vyhíbené $\mathrm{v}$ južnom cípe odkrytého areálu. $Z$ jeho celkovej plochy s rozlohou $4200 \mathrm{~m}^{2}$ zaberá novoveká fáza takmer $500 \mathrm{~m}^{2}$ (obr. 1).

Pre zemnice je príznačná kvadratická dispozícia centrálnej časti so zaoblenými nárožiami. V objekte 51 má horná obrysová línia rozmery $355 \times 340 \mathrm{~cm}$ a plochu $12 \mathrm{~m}^{2}$ (obr. 2:4).

Z juhovýchodnej strany sa v pozdížnej osi pripája rampovito sklonený výbežok vstupu s jazykovitým pôdorysom a dížkou $225 \mathrm{~cm}$. Vodorovne upravená podlaha objektu je od úrovne zistenia zahĺbená $118 \mathrm{~cm}$.

Línie juhozápadnej a severovýchodnej strany zemnice 53 sú v hornej úrovni súbežné, 


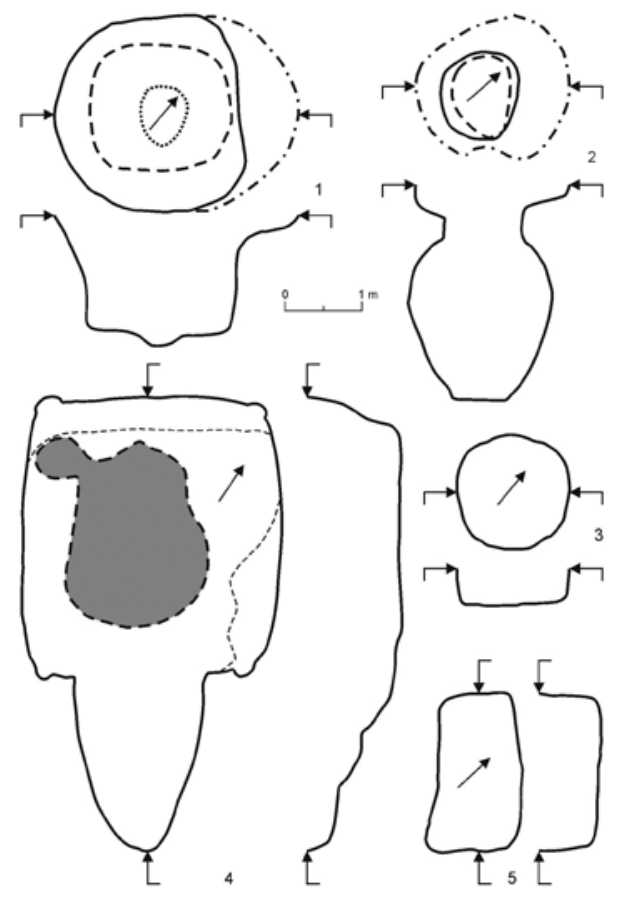

Obr. 2. Mužla-Čenkov. Plány sídliskových objektov. 1 -objekt 49; 2 -objekt 44;3-objekt $61 ; 4$-objekt 51; 5 -objekt 56. Kresba M. Hanuliak.

Abb. 2. Mužla-Čenkov. Planskizzen der Siedlungsobjekte. 1 - Objekt 49; 2 - Objekt 44; 3 - Objekt 61; 4 - Objekt 51; 5 - Objekt 56. Zeichnung M. Hanuliak. d’alšie dve protil'ahlé strany sa lichobežníkovito rozbiehajú o $60 \mathrm{~cm}$ (obr. 3:4). Výsledná plocha tak narástla na $17,6 \mathrm{~m}^{2}$. Steny sa nadol zošikmujú k rovnému dnu s rozmermi 400 $460 \times 385 \mathrm{~cm}$ a s plochou $16,5 \mathrm{~m}^{2}$. V severnom a východnom nároží sú pod úroveň podlahy vyhĺbené zásobné jamy s elipsovitým, resp. kruhovitým ústím, vakovitým profilom a rovným dnom v híbke $55 \mathrm{~cm}$ a $75 \mathrm{~cm}$. Prvá z nich má objem $0,6 \mathrm{~m}^{3}$, druhá $1,1 \mathrm{~m}^{3}$. Rovné dno centrálnej časti zemnice leží v híbke $100 \mathrm{~cm}$ od úrovne zistenia.

Interiér objektu sprístupňoval rampovito sklonený vstup s polkruhovým obvodom a dížkou $160 \mathrm{~cm}$ (obr. 3:4). Zaujímavé je, že sa tento útvar nepripája $\mathrm{k}$ centrálnej časti v pozdížnej, ale v zošikmenej línii v mieste západného nárožia. Horné obrysové línie centrálneho priestoru prerušujú štyri protilahlé dvojice polkruhových výbežkov s priemerom $20-25 \mathrm{~cm}$. Sú pozostatkom po stípoch osadených v stenách. Tvorili skelet konštrukcie slúžiacej k obloženiu hlinených stien bližšie neurčeným izolačným materiálom. V kolovej jame zo severozápadného vyústenia vstupného priestoru stál pôvodne stĺp tvoriaci oporu pre dvere uzatvárajúce predmetný interiér.

$\mathrm{Na}$ základe obloženia stien, existencie dvier a dvoch skladovacích jám možno objekt 53 označit' za zemnicu obytného charakteru. A to aj napriek tomu, že sa na jej dne nezistili doklady po kúrenisku, ktoré by vyhrievalo interiér a slúžilo na prípravu stravy. Pyrotechnologické zariadenia z identického časového úseku sa však nenašli ani na okolitej sídliskovej ploche. Tri prebádané kupolové pece horizontálneho typu známe $\mathrm{z}$ tohto areálu tvorili súčast' osady z poslednej tretiny 10. storočia (Hanuliak 2014, 682, obr. 4:5-7). Napriek tomu nemožno vylúčit' ani archeologicky zdokladovat' existenciu kúreniska vybudovaného v južnom nároží zemnice 53, ak stálo na podstavci z navŕšenej hliny a bolo po obvode vymedzené nehorl’avou obrubou. S určitost'ou sa nedá popriet' ani alternatíva, že kúrenisko nebolo v interiéri zostavené, pretože to nevyžadoval spôsob prevádzkovania objektu.

Ohňom prepálený povrch sa nezaznamenal ani na bloku z podložnej sprašovej hliny, vysokom $35 \mathrm{~cm}$, ktorý bol ponechaný v zemnici 51 (obr. 2:4). Jeho teleso s kulminujúcou šírkou $60 \mathrm{~cm}$ vybieha z východného nárožia a pokračuje pozdíž pril’ahlej interiérovej steny.

Spomenutý objekt sa od zemnice 53 odlišuje aj v iných detailoch. K podlahe je napríklad zošikmená iba severozápadná koncová stena, zvyšné sú zvislé (obr. 2:4). Skelet súžiaci k ich obloženiu izolačným materiálom tvoria dve dvojice protil’ahlých stĺpov, sčasti zapustených do profilov stien. Centrálnu čast' podlahy zaberá oválny kontext s priemerom ústia $210 \times 160 \mathrm{~cm}$, s úzkym výbežkom do západného nárožia. Steny tohto reprezentanta oblúkovito klesali do híbky $15-25 \mathrm{~cm}$ k výrazne zvlnenej línii dna. Z výplne sa nezískali artefakty, ktoré by sa dali zlúčit' s nejakou výrobnou činnostou. Sýtočierne sfarbenie hliny so zložkami mazlavej konzistencie je blízke výplni z pozdížnych vaňovitých objektov preskúmaných vo vrcholnostredovekej osade z Beckova, ktoré sa spájajú so zimným ustajňovaním chovaných zvierat (Hanuliak 2007, 341-342). Na základe tejto skutočnosti možno pripustit', že v čenkovskej zemnici 51 obytného 


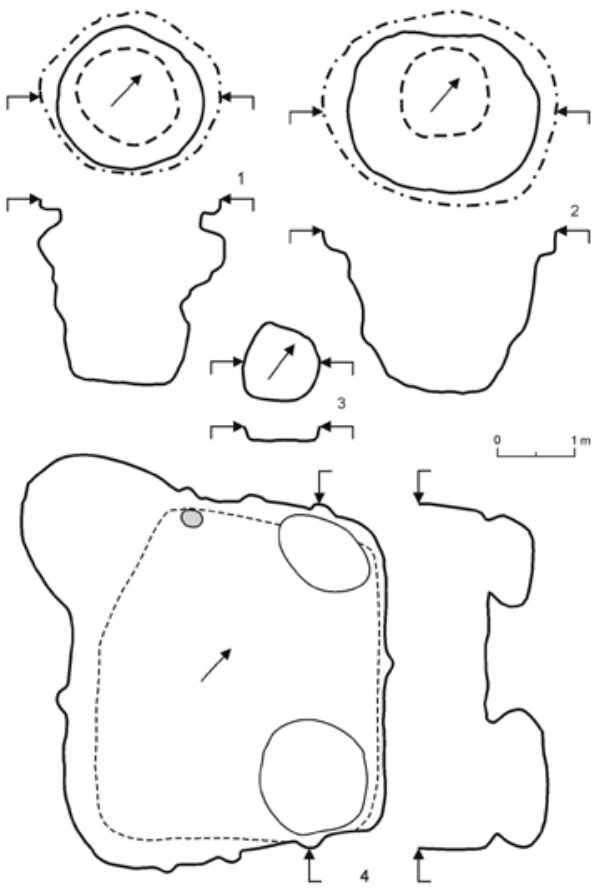

Obr. 3. Mužla-Čenkov. Plány sídliskových objektov. 1 - objekt 40; 2 - objekt 48; 3 - objekt 47; 4 - objekt 53. Kresba M. Hanuliak.

Abb. 3. Mužla-Čenkov. Planskizzen der Siedlungsobjekte. 1 - Objekt 40; 2 - Objekt 48; 3 - Objekt 47; 4 - Objekt 53. Zeichnung M. Hanuliak. typu mohli byt' istý čas ustajnené aj hospodárske zvieratá.

Kvadratická dispozícia oboch opisovaných zemníc bola pôvodne akiste prekrytá dvojspádovou strechou, ktorej odkvapové línie spočívali na obvodovom podklade $\mathrm{z}$ úrovne sídliskovej plochy. Prevýšenie strešného hrebeňa nad terénom nie je známe. Zahíbené dná objektov po líniu $100 \mathrm{~cm}$ a $118 \mathrm{~cm}$, navýšené iba o $30 \mathrm{~cm}$ mocnú nadložnú vrstvu zeminy, napriek tomu poskytovali dostatočný vertikálny limit potrebný $\mathrm{k}$ vol'nému pohybu osôb vo väčšinových častiach interiéru.

Medzi určujúcimi znakmi štyroch obilných zásobníc možno postrehnút' viacero prvkov. Patria k nim aj rozdiely zaznamenané v sformovaní zásobných priestorov. Zatial' čo objekt 48 má túto čast' $\mathrm{v}$ priereze kužel'ovito zúženú (obr. 3:2), obilnica 49 má zasa valcovitú podobu (obr. 2:1), v objekte 44 a 40 ide o hrncovitú formu dvoch rozdielnych typov (obr. 2:2; 3:1). V prvom je maximálna vydutina umiestnená pod zúženým hrdlom a steny sa kužel'ovito zbiehajú ku dnu. V druhom prípade sú steny od hrdla oblúkovito vyklenuté k vydutine dotvorenej nad polovičnou výškou priehlbne.

Zaznamenané nerovnosti v líniách stien nie sú rozhodujúce, pretože vznikli účinkom primárnych a sekundárnych činitel’ov. V obilných zásobniciach nadobúda väčší význam prepojenie ústia so zásobným priestorom. Ideálny variant predstavuje zúžené hrdlo umiestnené medzi obomi úsekmi, pretože poskytuje príležitost' k dôkladnému utesneniu uskladnených zásob pred prienikom vzduchu, povrchovej vody i hlodavcov, ktoré urýchl'ujú množenie roztočov a zhubných mikroorganizmov. Vd’aka takémuto riešeniu boli pol'nohospodárske produkty aj dlhodobejšie deponované bez obáv z hroziaceho znehodnotenia (Beranová 1980, 206-207; Kudrnáč 1970, 91-92).

$\mathrm{Z}$ tohto pohl’adu sú na skladovacie účely vhodnejšie najmä zásobnice 40 a 44 s hrncovitým profilom a hrdlom zúženým na $165 \mathrm{~cm}$ a $105 \mathrm{~cm}$ (obr. 3:1; 2:2). Ústie obilníc 48 a 49 má naproti tomu priemer $240 \mathrm{~cm}$ a $220 \mathrm{~cm}$ (obr. $3: 2 ; 2: 1$ ). To si akiste vyžiadalo využitie hrubšej vrstvy izolačnej upchávky, navršovanej na drevenú roštovú konštrukciu (Kudrnáč 1958, 246-247).

Nemenej dôležité sú aj rozmery príslušných línií zásobného priestoru, doplnené híbkou $155-280 \mathrm{~cm}$. Napriek rozdielom v hodnotách je objem v objektoch 40, 44 a 49 takmer jednotný a pohybuje sa v rozmedzí $3,2-3,5 \mathrm{~m}^{3}$. Tento štandard prevyšuje obilnica $48 \mathrm{~s}$ objemom $4,8 \mathrm{~m}^{3}$. Podla toho sa v štyroch objektoch dali uskladnit' zásoby s celkovým objemom $15 \mathrm{~m}^{3}$, ktoré prevyšujú potreby obyvatel'ov žijúcich v oboch zemniciach.

$\mathrm{K}$ príbuzným zložkám analyzovaných objektov patrí rovné dno. V objekte 49 bola v jeho strede umiestnená $17 \mathrm{~cm}$ hlboká priehlbeň s priemerom ústia $50 \mathrm{~cm}$ (obr. 2:1). Pre sporadický výskyt nebýva význam tohto útvaru jednoznačne interpretovaný, hoci sa častejšie vyskytuje vo včasnostredovekých zásobniciach. Dostupné informácie nepotvrdzujú spätost’ takýchto priehlbní s drenážnou funkciou, uvádzanou J. Kudrnáčom (1970, 93). 


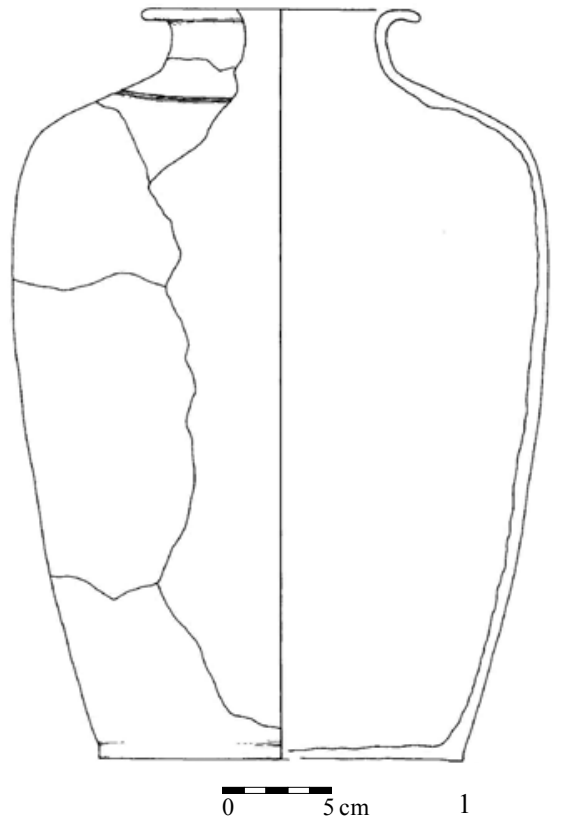

Obr. 4. Mužla-Čenkov. Keramická nádoba. 1 - objekt 53.

Abb. 4. Mužla-Čenkov. Keramikgefäß. 1 - Objekt 53 Zeichnung Ž. Nagyová. Kresba Ž. Nagyová.

K spoločným prvkom spracúvaných zásobníc takisto patrí kruhovitý útvar s rozšíreným priemerom, umiestnený nad ústím každého objektu. Aj ked' sa obvodové línie nezachovali $\mathrm{v}$ niekdajšej podobe, pôvodne akiste s dostatočným odstupom lemovali ústie objektov. Úroveň spodných úsekov týchto útvarov je takmer vodorovná a leží $15-30 \mathrm{~cm}$ od nivelety sprašového podložia (obr. 2:1, 2; 3:1-2). Takéto riešenie umožňovalo umiestnit' nad ústím všetkých objektov horizontálny drevený rošt $\mathrm{s}$ izolačným prekryvom. Takto zostavená upchávka, prekrytá $40-50 \mathrm{~cm}$ mocnou vrstvou hliny, nevyžadovala dodatočné navŕšenie zeminy nad ústím zásobnice. Jej poloha na pochôdznej úrovni zostala vd'aka tomu nepostrehnutel'ná. Pozoruhodné je, že sa takto upravený horný úsek nevyskytol ani u jednej z 200 obilných zásobníc, ktoré sa na čenkovskej lokalite používali $\mathrm{v}$ priebehu 9.-13. storočia (Hanuliak-Kuzma 2015, tabela $2,11)$.

$\mathrm{K}$ tretiemu typu sídliskových objektov patria tri zásobné jamy. Podla základných informácií ide o zástupcov odkrývaných $\mathrm{v}$ rôznom počte na každej stredovekej lokalite. $\mathrm{K}$ hojnejšie zastúpeným patria objekty s kruhovitým ústím, zvislými až zošikmenými stenami a rovným dnom. K takejto skupine patrí aj čenkovský objekt $47 \mathrm{~s}$ priemerom ústia $102 \mathrm{~cm}$ (obr. 3:3) a objekt $61 \mathrm{~s}$ priemerom $145 \mathrm{~cm}$ (obr. 2:3). Rozdielnost' $\mathrm{v}$ ich objeme s hodnotami $0,16 \mathrm{~m}^{3}$ a $0,7 \mathrm{~m}^{3}$ ovplyvnilo zahíbenie do úrovne $20 \mathrm{~cm}$ a $45 \mathrm{~cm}$. Objekt 56 patrí $\mathrm{k}$ zriedkavejším zástupcom s obdížnikovým pôdorysom s rozmermi $200 \times 100 \mathrm{~cm}$ a híbkou $72 \mathrm{~cm}$ (obr. 2:5). Okrem sporadických exemplárov materiálnej kultúry sa z výplne objektov nezískal materiál, ktorý by spresnil účel ich využívania. Aj preto sa nedá uviest' iná možnost', akou je krátkodobé uskladňovanie zásob s nižším objemom (Hanuliak-Kuzma 2015, 45).

\section{Materiálna kultúra}

Reprezentanti materiálnej kultúry sa vyskytli vo všetkých sídliskových objektoch. Dokonca aj v prostých zásobných jamách, v ktorých nálezy zvyčajne absentujú. Aj vd’aka tomu sa preskúmané objekty dali zlúčit' do jednotného chronologického rámca a oddelit' od reprezentantov z predchádzajúcich úsekov osídlenia lokality. Celková početnost' nálezov je napriek tomu nízka a kolekcia pozostáva iba z 37 kusov. Tradičné spektrum materiálnej kultúry má prevahu $(81,1 \%$ prípadov). Rovným dielom sú v nej zastúpené keramické nádoby a výrobky zo železa. Výnimočné predmety tvoria v súbore zvyšný diel (18,9\% prípadov), zastúpený tromi typmi výrobkov.

Zástupcovia keramických nádob, zachovaní v nadmerne zlomkovitom stave, pochádzajú z piatich objektov. Výnimkou je iba $35 \mathrm{~cm}$ vysoká nádoba s rekonštruovatel’ným tvarom, nájdená v centrálnej časti zemnice 53 (obr. 4:1). Má neobvyklý tvar, ktorý sa nedá jednoznačne pripojit' ani k jedinému známemu zástupcovi spomedzi súvekých hrnčiarskych výrobkov používaných pri varení a stolovaní. Telo má totiž fl'ašovitú formu s vysoko umiestnenou vydutinou s priemerom $24,8 \mathrm{~cm}$, zúžené nízke hrdlo a vodorovne vytiahnuté ústie má priemer $13,4 \mathrm{~cm}$. Z logického pohladu je takýto exemplár ideálny na uschovávanie tekutín. Keramickú hmotu reprezentuje 

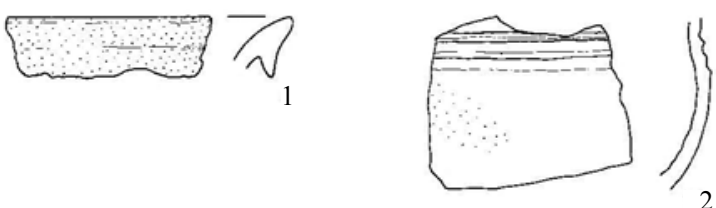

2

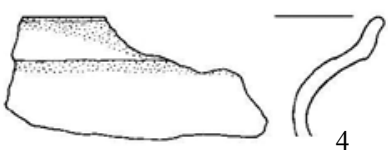

4
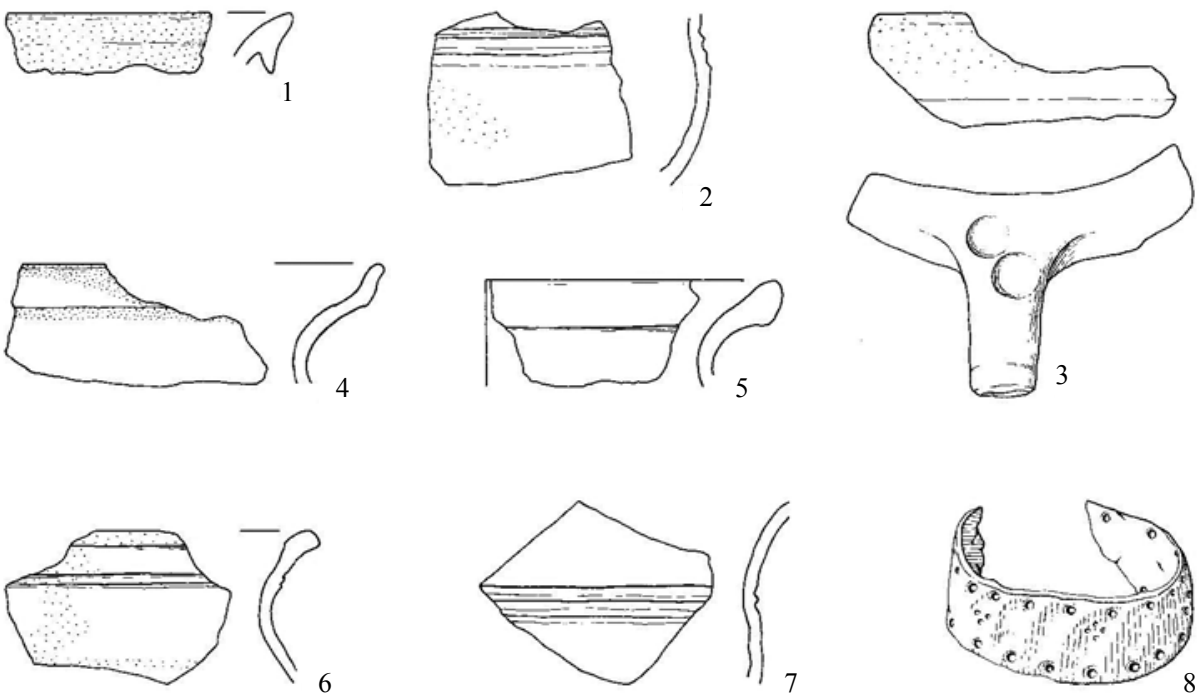

5
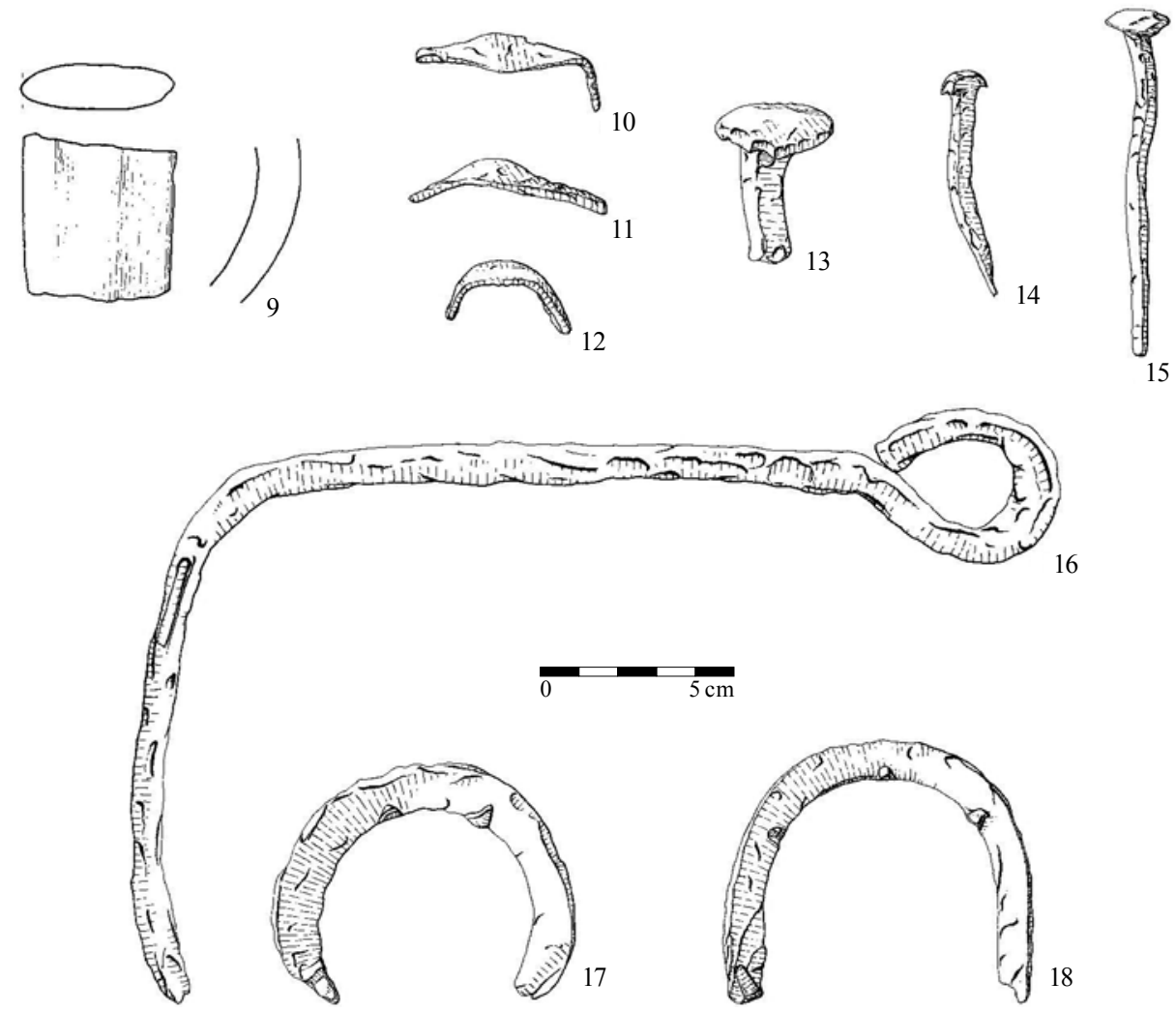

Obr. 5. Mužla-Čenkov. Predmety materiálnej kultúry. 1 - objekt 51; 2-3 - objekt 56; 4-7 - objekt 61; 8 - objekt 48; 9, 16 - objekt 49; 10-15 - objekt 53; 17-19-objekt 44. Kresba Ž. Nagyová.

Abb. 5. Mužla-Čenkov. Gegenstände der materiellen Kultur. 1 - Objekt 51; 2-3 - Objekt 56; 4-7 - Objekt 61; 8- Objekt 48; 9, 16 - Objekt 49; 10-15 - Objekt 53; 17-19- Objekt 44. Zeichnung Ž. Nagyová. 
bezprímesová režná zmes vytočená na hrnčiarskom kruhu s rýchlymi otáčkami, vypálená do sýtočervenej farby. Podl'a toho patrí do kolekcie tzv. farebnej keramiky s neglazovaným povrchom (Hoššo 1988, 112).

Identické technologicko-výrobné znaky sa objavujú aj na šiestich črepoch z troch stredne vysokých hrncovitých nádob s rozdielne sformovaným okrajom (obr. 5:1, 5). Iba exemplár so zahroteným previsnutým okrajom je na vnútornej strane pokrytý svetlozelenou glazúrou, presahujúcou na vonkajšiu stranu ústia (obr. 5:1). Zlomok z dolného úseku pásikového ucha elipsovitého prierezu naznačuje, že minimálne jedna z nádob bola obohatená o tento prvok (obr. 5:9). Podl’a sivého nádychu z povrchu sýtočerveného črepu pochádza spomenuté ucho z nádoby, ktorej dno sa našlo v objekte 56 a ústie s rímsovitým okrajom zasa v objekte 61 .

Ďalších šest' črepov patrilo k štyrom až piatim tenkostenným nádobám z okruhu tzv. bielej keramiky, pokrytých na vnútornej strane žltohnedou glazúrou (obr. 5:2, 4, 6, 7). Ich horné úseky pokrývali horizontálne žliabky, dve až tri línie tenkých rýh, výnimočne aj tmavočervené mal'ované pásy. Vzhl’adom k nadmernej zlomkovitosti nebolo možné stanovit' priemer ústia ani priblížit' tektoniku tela. Hrúbka stien do $0,2 \mathrm{~cm}$ naznačuje, že mohlo íst' o nízke džbánkovité alebo pohárovité exempláre s roztvoreným ústím a nevýrazne profilovaným okrajom (obr. 5:4, 6; Španihel 2014, 146, 148).

$\mathrm{Ku}$ kolekcii bielej keramiky patrí takisto nízka misovitá nádoba so zatiahnutým ústím. Jej vnútornú stranu pokrýva biela poleva, nanesená na svetlosivý podklad. Z d’alšej nádoby zasa pochádza krátky úsek dna s nôžkou, na koreni ktorej sa nachádzajú dve plytké priehlbne, jamky po prstoch výrobcu (obr. 5:3). Podl'a toho patrí zlomok k trojnôžkovej panvici, pokrytej zvnútra žltohnedou glazúrou (Čurný 2004, 67).

Zo železných predmetov sú najhojnejšie súčasti stavebných dielcov. Aj preto neprekvapí zvýšený počet klincov dlhých $6-9 \mathrm{~cm}$ s plochou, kvadratickou alebo krídlovou hlavicou (obr. 5:13-15) a dvojramenných skôb s elipsovitým stredom tela (obr. 5:10-12; Klíma 1980, 71, 76; Krajíc 2003, 64-67; Měchurová 2004, 236-238; Rusnák 2009, 394). Podl’a dierok po malých klincoch, husto zoradených pozdíž oboch okrajov, plnila spojovaciu funkciu aj objímka s vnútorným priemerom $5,5 \mathrm{~cm}$ (obr. 5:8). Vyrobená je z plechového pásu, hrubého $0,2 \mathrm{~cm}$, širokého $2 \mathrm{~cm}$. Iba v jedinom exemplári je zastúpený kl’úč najjednoduchšej hákovej formy, dlhý $23 \mathrm{~cm}$ (obr. 5:16). Jeden z koncov železnej tyčinky je zvinutý do kvapkovitého očka, druhý úsek ohnutý do pravého uhla meria $14 \mathrm{~cm}$. Na jeho konci neboli sformované zuby svedčiace o použití náročnejšej kováčskej techniky i vyššej zabezpečovacej schopnosti dreveného zámku s pohyblivou závorou (Klíma 1980, 42-48; Slivka 1981, 233).

Opotrebovaniu koženej obuvi so spevnenou podrážkou mali zabránit' železné podkovičky (Polla 1986, 196). Z obilnice 44 pochádzajú dva exempláre s viac i menej vyklenutým oblúkom a rozmermi $8 \times 6,2 \mathrm{~cm}$ a $6,8 \times 8 \mathrm{~cm}$ (obr. 5:17-18). Otvory po upevňovacích klincoch chýbajú. Ich funkciu nahradili plocho zahrotené výčnelky, umiestnené na vnútornej strane oblúka a koncoch každého ramena. Podl'a T. Cymbalaka (2006, obr. 11-12) mohli byt' oba rozdielne tvary upevnené na jedinej topánke - čižme.

$\mathrm{K}$ jazdeckej obuvi patriace ostrohy pochádzajú z dvoch objektov. Exemplár zo zemnice 53 má väčšie rozmery i výraznejšie sformované určujúce znaky (obr. 6:2). Ramená dlhé $11 \mathrm{~cm}$ sú intenzívnejšie prehnuté do päty vysokej $2 \mathrm{~cm}$. K nej sa takmer vodorovne pripája bodec dlhý $4,7 \mathrm{~cm}$. Na jeho konci je čapom pripevnené koliesko s priemerom $4,3 \mathrm{~cm}$, zložené zo šiestich lúčov. Kŕčok bodca spestrujú tri tenké plastické rebrá. Konce ramien sú sformované do kruhovitých upevňovacích očiek s priemerom $1,5 \mathrm{~cm}$, pričom remienok bol uchytený k oválnej platničke. Druhá ostroha zo zemnice 51 má $7,7 \mathrm{~cm}$ dlhé ramená, prehnuté s menšou intenzitou (obr. 6:1). Ukončujú ich kruhovité očká s priemerom $1 \mathrm{~cm}$. Bodec zdobený plastickým rebrom je dlhý $3,5 \mathrm{~cm}$. Koliesko so šiestimi lúčmi má priemer $2,8 \mathrm{~cm}$.

$\mathrm{K}$ výnimočným súčastiam spracúvaného súboru patria delové gule zo železa. $Z$ nich sa dva zlomky našli v obilnici 40 (obr. 6:5), d’alšie dva v zemnici 53 (obr. 6:3-4), zo zásobnej jamy 47 sa získal malý zlomok, dlhý $6,3 \mathrm{~cm}$. V prvom prípade sa z projektilu získala zhruba polovica a dvojtretinová čast', v druhom prípade tvoril nález polovicu a pätinu gule. Evidované exemplá- 
re zrejme pochádzajú z rôznych projektilov, pretože styčné plochy $\mathrm{k}$ sebe nepriliehajú a každý exemplár má odlišný priemer s hodnotou $9,8 \mathrm{~cm}, 10,4 \mathrm{~cm}, 10,6 \mathrm{~cm}, 11,2 \mathrm{~cm}$. Malý fragment zo zásobnej jamy, pochádzajúci z vnútornej časti, sa takisto nedá pripojit' k žiadnej guli. Variabilita v rozmeroch delových gúl' nesvedčí o dokonale zvládnutej technike ich formovania zo železnej zliatiny aj napriek tomu, že všetky boli určené pre jeden druh pol'ného štvorlibrového kanóna, označovaného termínom kartun (Pírek 2005, 15).

K zníženiu opotrebovávania liatych hlavní diel spomenutej kategórie takýmito strelami sa ich povrch pokrýval tenkou vrstvou olova alebo zliatiny z cínu a zinku (Letošták 2003, 104). Použitie takejto techniky dokladá amorfný zliatok oboch kovov, dlhý $5,4 \mathrm{~cm}$. Jeho zástupca z objektu 47 predstavuje súčasne druhý výnimočný exemplár nálezového fondu.

Posledným zástupcom z pertraktovanej kategórie je keramická dlaždica s hrúbkou $4 \mathrm{~cm}$, nájdená v objekte 53. Jedna zo zachovaných strán meria $14 \mathrm{~cm}$. Dlaždicu zhotovili z jemne plavenej ílovitej hliny s prímesou kamienkov rôznej vel'kosti. Intenzívnym výpalom získal tento výrobok v celom profile svetločervenú farbu. Na vonkajších plochách sa zachovali odtlačky drevenej štruktúry z dosiek tvoriacich obvodový rám formy. Menej časté sú odtlačky travín a tenkých konárikov. Ich čitatel'nost' je znížená na hornej pochôdznej ploche.

Zo zhlukového umiestnenia objektov vzdialených od seba 3-8 $\mathrm{m}$ aj spôsobu ich využitia vyplynie, že patria do identickej sídliskovej jednotky (obr. 1). Prítomnost' farebne odlíšitel'nej vrstvy spätej s týmto obdobím sa v pôdnom horizonte nezaznamenala. Podla tohto i chýbajúceho pyrotechnologického zariadenia a nepočetnej kolekcie materiálnej kultúry možno usúdit', že osídlenie spracúvanej lokality bolo krátkodobé. Čast' materiálnej kultúry ponechaná na úrovni terénu po zániku osídlenia odstránila strojová technika počas úpravy výskumnej plochy. Do sídliskových objektov sa presunuli nálezy tvoriace súčast' zásypovej zeminy.

K priblíženiu datovania spracúvaného osídlenia sú spomedzi materiálnej kultúry dôležité dve železné podkovičky, chrániace obuv na špici a opätku (obr. 5:17-18). Ku koženej obuvi neboli prichytené klinčekmi, ale plocho zahrotenými výčnelkami (Polla 1986, 196). T. Cymbalak (2006, 273; obr. 11-12) zaznamenáva používanie tohto typu v stredoeurópskom priestore až od prelomu 16. a 17. storočia. V priebehu 16. až polovice 17. storočia sa v pol'nom delostrelectve zasa používali kanóny, označované ako kartuny. Ich liate hlavne s dížkou 12-15 až 24 kalibrov bývali uložené v stenovej lafete s kolesovým podvozkom, t’ahaným dvomi až štyrmi koňmi (Dang1 1984, 172; Letošták 2003, 64). Z nich boli vystrel'ované aj železné liatinové gule s priemerom okolo $10 \mathrm{~cm}$, vážiace zhruba štyri libry (Letošták 2003, 64). Ide o taký typ projektilov, ktorých fragmenty sa získali z troch čenkovských objektov (obr. 6:3-5).

$\mathrm{S}$ takto vymedzeným časovým úsekom korešpondujú zlomky z tenkostenných nádob patriacich do kolekcie keramiky s bielym črepom a glazovanými vnútornými stenami (obr. 4:2-4, 6-7; Uličný 2004, 63). Voči tejto skupine pôsobia zdanlivo archaicky zlomky z dvoch hrncovitých nádob so sýtočerveným črepom, v ktorých absentuje glazúra na vnútornej strane (obr. 5:5). Používanie jednej z nádob ul’ahčovalo pásikové ucho (obr. 5:9), vnútorné steny tretieho exemplára chránila svetlozelená glazúra (obr. 5:1). Uvádzaní zástupcovia spomedzi hrncovitých, džbánkovitých či pohárovitých, misovitých nádob a panvíc sú identickí so včasnonovovekým sortimentom keramického riadu zhotovovaného od prelomu 16. a 17. storočia. Podl'a J. Hošša $(1988,112-121)$ v tejto kolekcii figuruje väčšina exemplárov z neskorostredovekej fázy s nevel'mi pozmenenou tektonikou tvarov, profiláciou ústia, glazovanými vnútornými stenami a sporadickými prípadmi rytej, žliabkovanej alebo mal'ovanej výzdoby. Pomerne ustálený je aj pomer výrobkov so sýtočerveným a bielym črepom, vyhotovených na rýchlorotujúcom hrnčiarskom kruhu. V jemne plavenej keramickej hmote chýba ostrivo. Jednotná farebnost' črepu poukazuje na kvalitný oxidačný výpal (Hoššo 2004, 571-572). Z ústnej informácie S. Španihela vyplýva, že spracúvaný súbor možno stotožnit's jeho IV. skupinou, používanou v rokoch 1600-1700 počas staršieho stupňa včasného novoveku. Pozornost' pertraktovaným vyvinutejším znakom venoval aj J. Hoššo (1997, 293-295; 2004, 570-571). Zdôraznil pritom úbytok hrncovitých foriem na úkor panvíc, fl'ašovitých voči džbánkovitým. Používaním hrnčiarskeho kruhu poháňaným nohami sa 

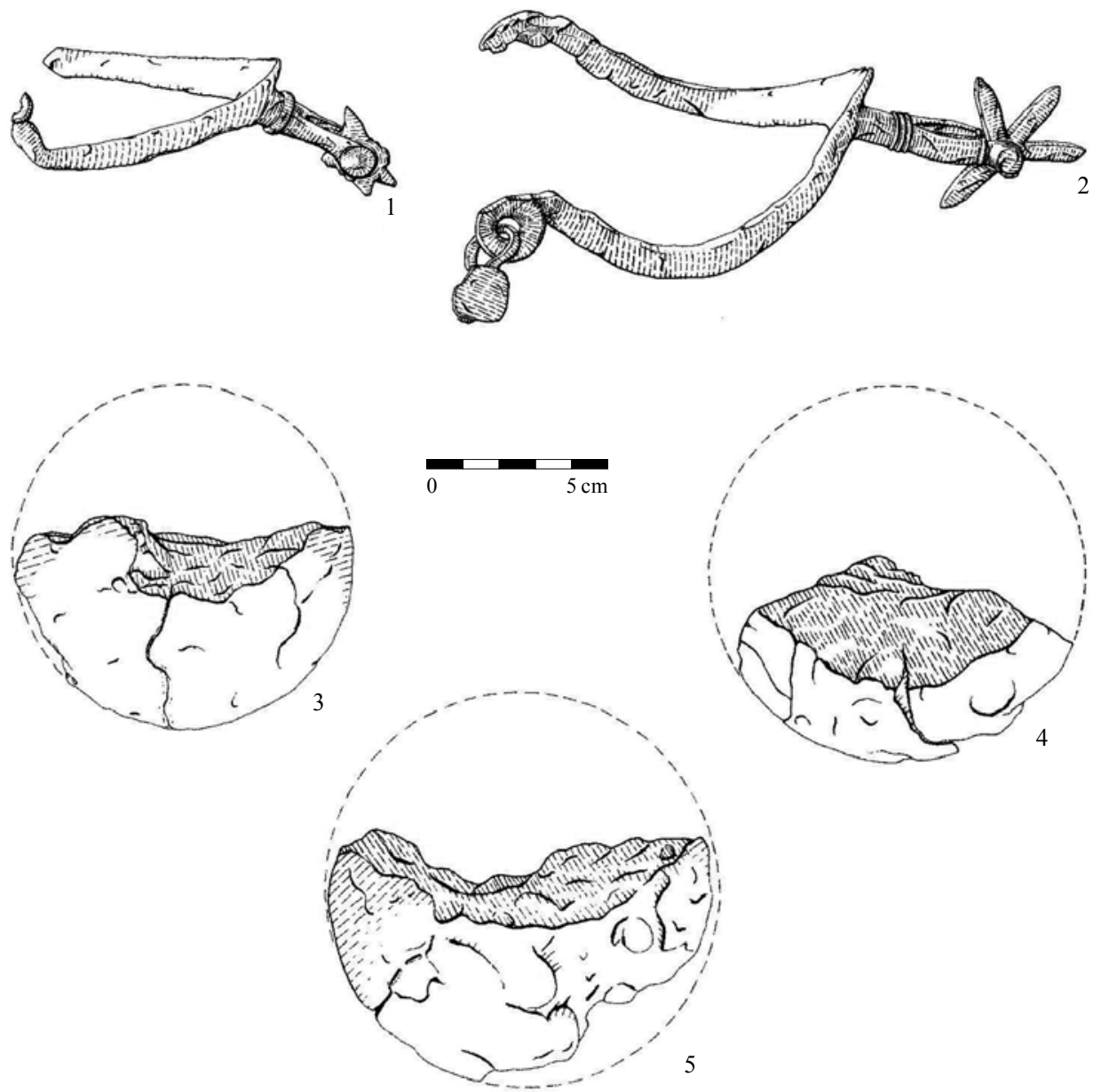

Obr. 6. Mužla-Čenkov. Predmety materiálnej kultúry. 1 - objekt 51; 2-4-objekt 53; 5 -objekt 40. Kresba Ž. Nagyová. Abb. 6. Mužla-Čenkov. Gegenstände der materiellen Kultur. 1 - Objekt 51; 2-4 - Objekt 53; 5 - Objekt 40. Zeichnung Ž. Nagyová.

zrýchlili obrátky, hrúbka črepu sa znížila, dno sa zrezávalo z podložky drôtom, bežným sa stalo glazovanie vnútornej strany nádob.

Vysoká flašovitá nádoba sa svojím tvarom i predpokladaným využitím z tejto kolekcie zdanlivo vymyká (obr. 4:1). V nálezových celkoch s bielym črepom sa napriek tomu sporadicky vyskytujú aj mierne modifikované fl'ašovité formy (Čurný 2004, 71).

$\mathrm{S}$ takto vymedzeným obdobím v plnom rozsahu nekorešpondujú dve ostrohy (obr. 6:1-2). Intenzita prehnutých ramien s tvarom upínacích očiek, uhlom nasadenia bodca k jeho koreňu, priemerom kolieska so šiestimi lúčmi patria k typickým parametrom v 14. storočí s presahom používania do 15. storočia (Koóšová 2004, 533-539, tab. 1-3). Na čenkovských exemplároch nie sú sformované prvky, pomocou ktorých sa vyhranené tvary ostrôh z 15.-16. storočia odlišujú od typov používaných $\mathrm{v}$ predchádzajúcom období. $\mathrm{K}$ týmto progresívnym prvkom patria obdížnikové upínacie platničky, striedané dvojicou očiek, manžetové tvary koreňa ostrôh a nadmerne predížené bodce. Uvedené zmeny si vyžiadalo zdokonalenie ochrany dolných končatín pláto- 
vým brnením i zmenená poloha jazdca v sedle (Holl-Parádi 1982, 83; Kalmár 1971, 361-363; Koóšová 2004, 536-539; Slivka 2004, 183-188; Wagner-Drobná-Durdík 1956, 52, 92-93).

Oddiely lahkej jazdy bojujúce bez plátového brnenia však nad’alej používali dostatočne účinné typy ostrôh vyvinuté v 14. storočí (Holl-Parádi 1982, 82). Toto zistenie nadobúda klúčový význam najmä v dedinskom prostredí, kde sa ostrohy prednostne používali na ovládanie koňa jazdcom pochádzajúcim z vidieckej komunity. Používanie rozdielne sformovaných typov ostrôh na odlišných lokalitách z vtedajšej sídliskovej štruktúry postrehla aj P. Koóšová (2004, 539, tab. 2). Z tohto pohl'adu nemusia zástupcovia $\mathrm{z}$ čenkovských objektov spochybňovat' stanovené datovanie spracúvaného osídlenia do priebehu prvej polovice 17. storočia. V tomto období, ako aj v neskorších úsekoch, sa podl’a etnologických prameňov nad’alej používali najjednoduchšie formy hákových klúčov, i ked' už nie na dôkladné uzamykanie, ale iba na spol’ahlivejšie uzatvorenie dverí. Z analyzovanej kolekcie sa vymyká keramická dlaždica používaná počas včasnohistorického obdobia. Na spracúvanú lokalitu bola zrejme prinesená z protilahlého dunajského brehu, kde sa nachádzajú zvyšky rímskej pevnosti Crumerum (Horváth-Kelemen-Torma 1979, 267).

\section{Zhodnotenie poznatkov}

V predchádzajúcich informáciách, získaných rozborom nálezového fondu, rezonujú dva momenty. Prvý súvisí s existenciou tohto útvaru v novovekej sídliskovej štruktúre, so zdôvodňovaním netypických znakov objektov a ich skladby. Druhý moment sa zasa spája s výnimočným výskytom vystrelených železných projektilov na lokalite, ktorá nepatrí k opevneným útvarom vyžadujúcim nasadenie delostreleckého oddielu k ich likvidácii.

Zo stotožnenia nálezovej situácie s úsekom z prvej polovice 17. storočia, poznačeným zložitými mocensko-politickými a vojenskými pomermi na predmetnom území vyplynie, že oba problematické momenty môžu súvisiet'. O ich výslednú podobu sa pričinilo dobytie ostrihomskej hradnej pevnosti osmansko-tureckými vojskami v roku 1543 a následné obsadenie prilahlého územia Slovenska z dunajského l'avobrežia. V priebehu nasledujúcich dvoch rokov vznikla $\mathrm{v}$ danom priestore nová územno-správna jednotka - sandžak. $\mathrm{K}$ povinnostiam jeho úradníkov patrilo zostavenie podrobných súpisov obyvatel'ov a majetkov. Na ich základe sa od miestneho obyvatel'stva každoročne vymáhali dane za hlavu a poplatky z majetku, hospodárskych aktivít a chovaných zvierat (Dangl 1984, 70; Kopčan-Krajčovičová 1983, 109; Zemanová 2015, 21).

Tento odvodový systém nachádzal oporu v islamskom práve, ktoré uzákonilo vymáhanie príslušných poplatkov od porobených inovercov. Odvodové povinnosti domácich obyvatel’ov v prospech uhorskej aristokracie pritom nezanikli. Vplyvom tejto duálnosti dochádza vo vidieckom prostredí $\mathrm{k}$ nadmernej ekonomickej zát’ǎi, ktorá sa prejavila v redukcii osídlenia. Následkom toho sa na území historického Hontu v prelomovom úseku 16. a 17. storočia znížil počet zdaňovaných poplatníkov na štvrtinu pôvodného množstva. Situáciu navyše zhoršovali pustošivé rabovačky, násilné odvliekanie l'udí na nútené práce, vymáhanie výkupného za zajatých jedincov a ich predaj do otroctva (Blaskovics 1986, 23-25; Dangl 1986, 38; Kopčan-Krajčovičová 1983, 27, 36, 43, 48).

Zmienky o zbiehaní obyvatel'ov z dedín a ich ukrývaní na odlahlých miestach sa zrejme spájajú s krátkodobými prípadmi, pretože únik z reálneho hospodárstva pred vyberačmi daní nejestvoval (Dangl 1984, 88). Aj čenkovský sídliskový útvar sa neprejavuje ako dočasné útočisko l'udí, ktorí z okolitých regulárnych sídliskových jednotiek unikli počas náhleho prepadu. Založenie čenkovského zoskupenia objektov si totiž vyžiadalo dlhodobejšiu výkopovú a stavebnú činnost'. Uskladnené zásoby zasa prevyšovali stravovacie potreby jedincov z dvoch zemníc. Druhá z nich sa pritom zrejme využívala aj na ustajnenie chovaných zvierat.

Súčasne sa nedajú prehliadnut' indície o krátkodobom používaní preskúmaných objektov. Okrem nedotvorenej sídliskovej vrstvy o tom presviedčajú chýbajúce kúreniská, potrebné k príprave stravy a vykurovaniu interiérov. Predmety každodenného využitia s dokladmi o úprave produktov a výrobnej činnosti absentujú. V nepočetnej škále riadu sú zlomky kuchynskej 
a stolovacej keramiky vzácne vyrovnané. Napriek tomu je ich typologická škála zúžená na štvrtinu obvyklej zostavy.

Zemnice poskytujú taktiež nižší štandard bývania než viacpriestorové hlinené domy z úrovne terénu, predstavujúce základ rol’níckych usadlostí v súvekom dedinskom prostredí (Botík 1998, 69-77). Počas odstraňovania nadložných vrstiev zeminy z výskumnej plochy sa pri kontrolovanom dohl'ade nezistili indície o existencii takýchto domov, do ktorých by boli odkryté zemnice zakomponované $\mathrm{v}$ podobe podpivničených komôr. Výkopom archaických foriem interiérov sa zrejme sledoval zámer ukryt' alebo zamaskovat'v teréne ich existenciu. Podobný efekt sa sledoval aj v prípade obilných zásobníc. Prejavil sa vo vyhĺbenom obvodovom prstenci lemujúcom ich ústie.

Celkový objem uskladnených agrárnych produktov spochybňuje zaradenie sídliskovej jednotky medzi roztratené sídla zakladané od 16. storočia v rámci vnútorných kolonizačných procesov (Botík 1998, 71-72). Podl’a zistených skutočností nepatrí čenkovská skupina objektov k tradičným sídelným jednotkám. Lokalita sa do vtedajšej štruktúry začleňuje ako výnimočný, účelovo sformovaný segment. Jeho štruktúru dotvorili objekty zoradené v severo-južných líniách. Základný prvok tvoria obe zemnice a štyri obilnice umiestnené v popredí. Do okrajových úsekov boli odsunuté prosté zásobné jamy. Ich poloha súčasne presviedča, že sa archeologickým výskumom odkryl kompletný útvar.

Akiste nejde o náhodu, ked’ sa k umiestneniu spracúvaných objektov zvolil vyvýšený úsek dunajského brehu s upraveným prístupom k riečnemu prepravisku (Hanuliak-Kuzma-Šalkovský 1993, 166). Ak uskladnené zásoby patrili k vrchnostenským dávkam sústredeným pre uhorských pozemkových vlastníkov, mohli sa vd’aka prepravisku transportovat' riečnou trasou. Od začiatku 17. storočia spol'ahlivost' takejto prepravy zvyšovali lode s rakúskymi vojakmi, vyzbrojené delami. Išlo o tzv. „,navy“ dlhé až 25 m, široké 4,5 m, plávajúce po Dunaji (Letošták 2003, 173). Suchozemská cestná siet’ bola, naopak, kontrolovaná osmansko-tureckými okupantmi. Ich početná posádka sídlila na území ned’alekého Štúrova, označovaného ako Džigerdelen-Parkan. Podla písomných prameňov patrili k vojenským jednotkám aj strelmajstri - topčovia s ôsmimi delami (Blaskovics 1986, 26; Kopčan-Krajčovičová 2003, 166-170; Kuzma-Bartík 2016, 146-147).

Nevyhnutným vozatajstvom $\mathrm{k}$ transportu diel, k prevozu munície a pušného prachu disponovalo iba regulárne vojsko. S niektorou z jeho akcí́ by sa dala zrejme spojit’ aj likvidácia čenkovského sídliskového segmentu. Intenzitu cieleného útoku zvýšilo niekol'ko výstrelov z dela, ktorých projektily sa rozpadli po náraze na pevnú prekážku. Dnes sa sotva dá spresnit', či išlo o stavebnú konštrukciu objektov alebo o kmene stromov z lužného lesa, maskujúce toto sídlo.

Predchádzajúce názory nie sú s určitost’ou jediné, ktoré sa snažia priblížit' význam odkrytého sídliskového útvaru, osvetlit' okolnosti jeho vzniku i zániku, interpretovat' súčasti nálezového fondu. K potvrdeniu ich správnosti chýba potrebná kvalita vypovedacích schopností hmotných prameňov.

Štúdia bola vypracovaná v rámci projektu 2/0037/17 Agentúry VEGA.

\section{Literatúra}

BERANOVÁ, M., 1980: Zemědělství starých Slovanů - Die Landwirtschaft der älter Slawen. Praha.

BLASKOVICS, J., 1986: Nové Zámky pod osmansko-tureckou nadvládou (1663-1685), Castrum Novum 3, 23-84.

BOTÍK, J., 1998: Geografické, kultúrno-spoločenské a interetnické súvislosti l’udovej architektúry. In: L'udová architektúra a urbanizmus vidieckych sídiel na Slovensku z pohl'adu najnovších poznatkov archeológie a etnografie, 67-101. Bratislava. 
CYMBALAK, T., 2006: Wybrane znaleziska podkówek do butóv z terenu Czech na tle analogii środkowoeuropejskich - Selected Finds of Shoe Fittings from Czech Republic in the Central European Context, Archaeologia Pragensia 18, 264-282.

ČURNÝ, M., 2004: Keramika zo 16.-18. storočia na juhozápadnom Slovensku na príklade nálezov z kaštiel’a v Lukáčovciach. Diplomová práca na FF UKF v Nitre.

DANGL, V., 1984: Bitky a bojiská od Wogastisburgu po Lamač. Bratislava.

- 1986: Slovensko vo víre stavovských povstaní. Bratislava.

HANULIAK, M., 2007: Vrcholnostredoveká osada v Beckove - Die hochmittelalterliche Siedlung in Beckov, AH 32, 335-349.

- 2014: Sídlisko z poslednej tretiny 10. storočia v Orechovom sade z Mužle-Čenkova - Ein Siedlung aus dem letzten Drittel des 10. Jahrhunderts in der Lage Orechový sad aus Mužla-Čenkov, AH 39, 679-688.

HANULIAK, M.-KUZMA, I., 1991: Desiata sezóna výskumu v Mužle-Čenkove - Zehnte Grabungssaison in Mužla-Čenkov. In: AVANS 1989, 35-37. Nitra.

- 2015: Mužla-Čenkov II. Osídlenie z 9.-13. storočia - Mužla-Čenkov II. Besiedlung aus dem 9.-13. Jahrhundert. Nitra.

HANULIAK, M.-KUZMA, I.-ŠALKOVSKÝ, P., 1993: Mužla-Čenkov I. Osídlenie z 9.-12. storočia Mužla-Čenkov I. Besiedlung aus dem 9.-12. Jahrhundert. Nitra.

HOLL, I.-PARÁDI, N., 1982: Das mittelalterliche Dorf Sarvaly. Budapest.

HORVÁTH, I.-KELEMEN, M.-TORMA, I., 1979: Komárom megye régeszeti topografiája. Magyarország régeszeti topografiája 5 . Budapest.

HOŠŠO, J., 1988: Hrnčiarstvo. Remeslo stredovekej dediny a mesta vo svetle archeologických premien Die Töpferei. Das Handwerk mittelalterlicher Dörfer und Städte in Licht archäologischer Quellen, Zborník FF UK, História 35-36, 105-139.

- 1997: Príspevok k štúdiu materiálnej kultúry na území Bratislavy v období stredoveku a začiatkom novoveku - Beitrag zum Studien der Sachkultur auf dem Bebiet Des Bratislava im Mittelalteer und Aufgang der Neuzeit, AH 22, 287-300.

- 2004: Hranica medzi stredovekom a novovekom vo svetle archeologických nálezov - Zur Grenze zwischen dem Mittelalter und dem Neuzeit im Lichte der archäologischen Keramikfunde, AH 29, 569-580.

KALMÁR, J., 1971: Régi magyar fegyverek. Budapest.

KLÍMA, B., 1980: Zámečnická práce staromoravských kovářů v Mikulčicích - Schlosserarbeit der großmährischen Schmiede in Mikulčice. Praha.

KOÓŠOVÁ, P., 2004: Ku klasifikácii vrcholnostredovekých ostrôh z územia Slovenska (12.-15. storočie) Zur Klassifikation der hochmittelalterlichen Sporen auf dem Gebiet der Slowakei (12.-15. Jh.), AH 29, 523-547.

KOPČAN, V.-KRAJČOVIČOVÁ, K., 1983: Slovensko v tieni polmesiaca. Bratislava.

KRAJÍC, R., 2003: Kovárna v Sezimově Ústí a analýza výrobků ze železa. Archeologie středověkého poddanského města 3. Díl I. - Die Schmiede in Sezimovo Ústí und Analyse der Produkte aus Eisen. Sezimovo Ústí - Archeologie der mittelaltelichen Unterstadt 3. Teil I. Praha - Sezimovo Ústí - Tábor.

KUDRNÁČ, J., 1958: Sklady obilí v jamách obilnicích - Lagerung von Getreide in Gruben-Speichern. In: Vznik a počátky Slovanů II, 233-252. Praha.

- 1970: Klučov. Staroslovanské hradiště ve středních Čechách - Klučov. Ein altslawischer Burgwall in Mittelböhmen. Praha.

KUZMA, I.-BARTÍK, M., 2016: Turecké opevnenie v Štúrove - Türkische Befestigung in Štúrovo. In: AVANS 2010, 146-148. Nitra.

LETOŠŤÁK, L', 2003: Delostrelectvo čierneho prachu. Ružomberok.

MĚCHUROVÁ, Z., 2004: Kovové a luxusní nálezy z hradu Landeka u Ostravy (kat. Koblov) - Metallund Luxusgegenstände aus der Burg Landek bei Ostrava (Gem. Koblov), ČMMZ, Vědy společenské LXXXIX, 219-252.

PÍREK, M., 2005: Grafika Matiáša Seuttera, dokument vojenskej histórie z prelomu 17. a 18. storočia - The Graphical Art Work by Matias Seutter, the Document of Military History from the Turn of the 17th and 18th Centuries, ZbSNM 99, História 45, 5-26.

POLLA, B., 1986: Košice-Krásna. K stredovekým dejinám Krásnej nad Hornádom - Košice-Krásna. Zur mittelalterlichen Geschichte von Krásna nad Hornádom. Košice.

RUSNÁK, R., 2009: Novšie nálezy stredovekých kovových predmetov z Košíc - Die neuesten Funde mittelalterlicher Metallgegenstände aus Košice, AH 34, 393-407.

SLIVKA, M., 1981: Stredoveké hutníctvo a kováčstvo na východnom Slovensku. 3. čast', Historica Carpatica $12,211-276$. 
- 2004: Tzv. manžetové ostrohy z územia Slovenska - Die sog. Manschettensporen auf slowakischen Gebiet, ZbSNM XCVIII, Archeológia 14, 183-190.

ŠPANIHEL, S., 2014: Stredoveká a novoveká keramika zo severozápadného Slovenska - Medieval and modern ceramic in north-western Slovakia, ŠZ AÚ SAV 55, 141-181.

ULIČNÝ, M., 2004: Premeny východoslovenskej keramiky v 13.-17. storočí na podklade analýzy keramického riadu z hradu Šariš. Dizertačná práca na FF PU v Prešove.

WAGNER, E.-DROBNÁ, Z.-DURDÍK, J., 1956: Kroje, zbroj a zbraně doby předhusitské a husitské. Praha.

ZEMANOVÁ, O., 2015: Filakovský hrad - kamenný svedok protitureckých bojov, Kontexty kultúry a turizmu $1,19-24$.

\section{Zusammenfassung}

\section{Ein neuzeitliches Siedlungssegment aus Mužla-Čenkov}

Am Rande der heutigen Siedlung Čenkov wurde im Jahr 1989 auf einem ausgedehnten Areal eine Grabung durchgeführt. Dabei wurden auf einer Fläche von $500 \mathrm{~m}^{2}$ neun Siedlungsobjekte freigelegt (Abb. 1). Diese Gruppe bilden zwei Grubenhäuser mit quadratischem Grundriss und nach Innen geneigtem Eingang (Abb. 2:4; 3:4). Die zentralen Teile haben eine Fläche von jeweils $12 \mathrm{~m}^{2}$ und $16,5 \mathrm{~m}^{2}$. Ihre ebenen Böden sind jeweils $118 \mathrm{~cm}$ und $100 \mathrm{~cm}$ von der Höhenlinie des Untergrundes eingetieft. In den Wänden sind Abdrücke erhalten geblieben, die von einer zur Verkleidung der Lehmwände dienenden Säulenkonstruktion stammen. In Objekt 53 wurden zwei Vorratsgruben entdeckt (Abb. 3:4). Auf dem Fußboden von Grubenhaus 51 befand sich der ovale Kontext einer dunklen Farbe, der durch eingestalltes Vieh gebildet wurde. In keinem einzigen der Objekte wurden pyrotechnologische Anlagen errichtet. Vier Getreidevorratsgruben haben ein unterschiedliches senkrechtes Profil (Abb. 2:1-2; 3:1-2). Demnach bewegt sich der Durchmesser der Mündung zwischen $102-240 \mathrm{~cm}$ und die Tiefe zwischen $155 \mathrm{~cm}$ und $280 \mathrm{~cm}$. Im Innern der Getreidegruben konnten Vorräte mit einem Fassungsvermögen von insgesamt $15 \mathrm{~m}^{3}$ gelagert werden. $\mathrm{Zu}$ den gemeinsamen Merkmalen aller Objekte zählt ein eingetiefter Abschnitt, der den Umfang der Mündung säumt und dazu diente, ihre Lage im Gelände zu verbergen. Drei einfache Vorratsgruben haben einen runden und rechteckigen Grundriss (Abb. 2:3, 5; 3:3). Ihr Fassungvermögen hat den Wert von 0,16-1,4 $\mathrm{m}^{3}$.

$\mathrm{Zu}$ den 37 Exemplaren der materiellen Kultur zählt ein hohes flaschenförmiges Gefäß (Abb. 4:1). Häufiger sind Bruchstücke von topfartigen Gefäßen (Abb. 5:1, 5, 9), Krügen oder Bechern (Abb. 5:2, 4, 6-7). Eine Schüssel und Pfanne sind Einzelfunde (Abb. 5:3). Von den Eisengegenständen sind zwei Hufeisenbeschläge von Schuhen (Abb. 5:17-18), zwei Sporen (Abb. 6:1-2), fünf Kanonenkugelfragmente (Abb. 6:3-5) und ein Schlüssel (Abb. 5:16) von Bedeutung. Diese Funde datieren den Siedlungskomplex in die erste Hälfte des 17. Jahrhunderts.

Nach der Analyse des Fundbestandes entsteht die Notwendigkeit, strittige Momente zu erläutern. Dazu gehört die Begründung für die Existenz dieses außergewöhnlichen Siedlungsgebildes in der traditionellen Siedlungsstruktur, das Vorkommen von Kanonenkugeln an einem nicht befestigten Standort in landwirtschaftlicher Umgebung. Bei der Klärung der genannten Probleme muss der nur kurzzeitigen Besiedelung der Fundstelle, den Ausprägungen der getarnten Objekte im Gelände sowie deren Nutzungsart Rechnung getragen werden. Den gewonnenen Erkenntnissen nach zählte dieses Gebilde nicht zu den landwirtschaftlichen Streusiedlungen. Es handelt sich hier um eine zweckdienlich gebildete Gruppierung, in welcher offenbar die Abgaben für die ungarischen Grundstückseigentümer gesammelt wurden. Ihr Transport über die Landwege war nicht möglich, da der Süden der Slowakei damals von den osmanisch-türkischen Eroberern besetzt war. Das Flußnetz über die Donau war demgegenüber frei. Offenbar wurden die Lagerräume aus diesem Grund am Rand des Donauufers im benachbarten Hafen angelegt. Eine gewaltsame Liquidierung einer solchen Vorratsbasis konnten die militärischen Truppen der osmanisch-türkischen Garnison angestrengt haben, die im nahegelegenen Štúrovo stationiert 
waren. Ihrer Ausrüstung wurden auch die Kanonen zugeordnet, die zur Verteidigung und Abschreckung der lokalen Bevölkerung gedacht waren.

Die vorliegende Studie wurde im Rahmen des von der Agentur VEGA geförderten Projekts 2/0037/17 ausgearbeitet.

PhDr. Milan Hanuliak, DrSc., Archeologický ústav SAV, Akademická 2, SK 94921 Nitra, Slovenská republika, milan.hanuliak@savba.sk 
